NOTE

\title{
Functional diversity in amphipods revealed by stable isotopes in an eelgrass ecosystem
}

\author{
J. P. Farlin ${ }^{1, *}$, L. S. Lewis ${ }^{1,2}$, T. W. Anderson ${ }^{1}$, C. T. Lai ${ }^{1}$ \\ ${ }^{1}$ Department of Biology and Coastal \& Marine Institute, San Diego State University, 5500 Campanile Drive, San Diego, \\ California 92182-4614, USA \\ ${ }^{2}$ Present address: Center for Marine Biodiversity and Conservation, Scripps Institution of Oceanography, \\ 9500 Gilman Drive, La Jolla, California 92083-0202, USA
}

\begin{abstract}
Amphipods are often dominant components of benthic marine communities and may exhibit taxon-specific differences in feeding behavior. As a result, variation in the composition of amphipod communities is an important metric for the interpretation of trophic dynamics in benthic marine ecosystems. Though previous studies of amphipod diets indicate functional diversity among taxa, few studies have examined whether these differences are detectible using time-integrated natural tracers of in situ feeding habits. We used stable isotope ratios of nitrogen $\left(\delta^{15} \mathrm{~N}\right)$ and carbon $\left(\delta^{13} \mathrm{C}\right)$ to examine trophic structure among amphipod taxa belonging to 5 families in an eelgrass (Zostera marina) ecosystem in San Diego Bay, California. The relative contribution of sources of primary production to amphipod diets was further analyzed using a mixing model bracketed by 2 dominant sources of primary production in the system: eelgrass and algae. We detected significant differences in both $\delta^{13} \mathrm{C}$ and $\delta^{15} \mathrm{~N}$ among amphipod taxa, indicating family-specific differences in feeding habits that generally agree with previous studies of amphipod diets. Hyalids fed almost exclusively on eelgrass, ischyrocerids and ampithoids tended to feed more on algae and eelgrass, respectively, and caprellids exhibited heterogeneous feeding on both algae and eelgrass. The relatively high $\delta^{15} \mathrm{~N}$ value of oedicerotids suggested that this group was likely carnivorous. Our findings are in general agreement with previous descriptions of family-specific amphipod feeding behaviors, suggesting that stable isotopes are a useful tool for describing the functional roles of mesograzers in eelgrass ecosystems.
\end{abstract}

KEY WORDS: Functional diversity $\cdot$ Stable isotopes $\cdot$ Eelgrass food web $\cdot$ Amphipods $\cdot$ Amphipod feeding

Resale or republication not permitted without written consent of the publisher

\section{INTRODUCTION}

Trophic interactions structure communities and influence productivity across multiple trophic levels (Paine 1980, Heck \& Valentine 2007). Most studies demonstrating such interactions in benthic marine habitats have focused on the effects of macrograzers (e.g. fishes, sea urchins and mollusks), whereas smaller mesograzers (e.g. amphipods) have received relatively less attention (Thayer et al. 1978, Duffy \&
Hay 2000). Mesograzers, however, can exhibit interaction strengths similar to macrograzers (Sala \& Graham 2002) and may exert strong top-down effects on the structure and productivity of benthic macrophyte assemblages (Duffy \& Hay 2000). Amphipods are particularly important in eelgrass ecosystems because they are significant consumers of primary production and graze preferentially on epiphytic algae, which in turn enhances eelgrass production (Kitting et al. 1984, Orth \& Van Montfrans 1984). Determining whether 
amphipods are grazing on an algal-based or eelgrassbased (living or detrital tissue) food source has implications on their net (positive, negative, or neutral) effects on ecosystem primary production.

In studies of marine food webs, amphipods are often grouped into a single trophic guild based on the assumption that they are functionally redundant (Thayer et al. 1978, Kitting et al. 1984, Bell 1991, Fredriksen 2003, Nagelkerken et al. 2006, Davenport \& Anderson 2007). This assumption, however, has been challenged due to contrary evidence provided by feeding assays and gut content analyses (Poore 1994, Duffy \& Harvilicz 2001). Though such studies provide valuable insight into feeding behaviors of amphipods, they are limited to observing individual grazing behaviors as snapshots in time (e.g. gut contents) or under less realistic conditions (e.g. laboratory assays and mesocosms).

The diversity of amphipod feeding behaviors in the wild remains an important gap in our knowledge of benthic ecosystems (Duffy \& Hay 1991) and is crucial to our understanding of food web dynamics in these systems (Poore et al. 2008). One method of exploring the feeding history and trophic diversity of wild organisms is through the use of stable isotope ratios of carbon $\left({ }^{13} \mathrm{C} /{ }^{12} \mathrm{C}\right)$ and nitrogen $\left({ }^{15} \mathrm{~N} /{ }^{14} \mathrm{~N}\right)$, whereby carbon is used to trace primary production and nitrogen to infer trophic level (Peterson \& Fry 1987). Our objective was to use stable isotopes to examine the feeding history of 5 amphipod taxa, each within a different family (Ampithoidae, Caprellidae, Hyalidae, Ischyroceridae, and Oedicerotidae) within an eelgrass (Zostera marina) ecosystem in San Diego, California. We selected these 5 amphipod families because they were common in the study area (Lewis 2009), were readily identified using taxonomic keys (e.g. Chapman 2007), and were expected to exhibit different modes of feeding based on previous research and jaw morphology (Chapman 2007). We then examined whether our findings based on stable isotope ratio analyses agreed with previous descriptions of family-specific feeding behaviors.

\section{MATERIALS AND METHODS}

Study area and collection. Amphipods, filamentous epiphytic algae, eelgrass, and eelgrass detritus were collected haphazardly during low tide from ca. $100 \mathrm{~m}^{2}$ of eelgrass habitat adjacent to Shelter Island in San Diego Bay, California. This site was chosen to take advantage of the existing infrastructure associated with ongoing research (Lewis 2009). At low tide, researchers waded into the eelgrass bed to a depth of approximately $0.5 \mathrm{~m}$ prior to collecting samples. Eelgrass samples, containing epiphytic algae and epi- fauna, were pulled by hand and immediately placed in $500 \mu \mathrm{m}$ mesh bags. The benthos was then skimmed to collect detritus and benthic amphipods. A total of 9 grab samples and 8 benthic samples were collected on 18 October and 13 November, 2008. All samples were immediately placed on ice and transported to the laboratory for processing. In the lab, epiphytic algae and fresh young eelgrass leaves were isolated from grab samples. The remaining eelgrass samples were thoroughly rinsed with deionized water over a $500 \mu \mathrm{m}$ sieve to isolate amphipods from other material. Benthic samples were also rinsed over a $500 \mu \mathrm{m}$ sieve, and amphipods and detrital (i.e. dead and decaying) eelgrass were removed and isolated. All samples were frozen $\left(-20^{\circ} \mathrm{C}\right)$ until preparation for stable isotope analysis. We intended to sample macroalgae, but none were present in the eelgrass bed during sampling. Epiphytic filamentous algae were analyzed and interpreted as a general 'algal signature' on the basis of the assumption that macroalgae and filamentous algae have similarly depleted $\delta^{13} \mathrm{C}$ values (approximately $10 \%$ less) than those of eelgrass (Currin et al. 1995, Moncreiff \& Sullivan 2001).

Amphipod identification. Amphipods were sorted to family according to Chapman (2007). We used this taxonomic category because identification of amphipods to genus and species was not feasible for all sexes and stages of specimens used in our study (Chapman 2007). We later identified the numerically dominant genus within each family (Table 1) by further examining identifiable voucher specimens with taxonomists from the San Diego City Metropolitan Waste Water District.

Sample preparation and stable isotope analysis. Samples were thawed, sorted in clean Petri dishes, and then rinsed with deionized water to remove residual salt water. Amphipods were sorted to family and individuals were pooled $(\mathrm{n} \approx 5$ to 45 per replicate sample; Table 1) to attain adequate material for isotope analyses (1.0 to $2.0 \mathrm{mg}$ dry wt). Young eelgrass leaves, detrital eelgrass, and epiphytic algae were cleaned of all fouling material prior to processing and analysis. All samples were placed in a drying oven at $60^{\circ} \mathrm{C}$ for $48 \mathrm{~h}$, homogenized, placed into tin capsules and weighed. Isotopic ratios were measured by combustion using continuous-flow isotope-ratio mass spectrometry at San Diego State University's (SDSU) Ecology Analytical Facility (Thermo Scientific DeltaPlus Advantage IRMS, $\mathrm{n}=66$ ) and the Stable Isotope Facility at the University of California, Davis (PDZ Europa 20-20 IRMS, $\mathrm{n}=33$ ). Stable carbon and nitrogen isotope ratios of a sample were measured against laboratory reference materials selected to be compositionally similar to the samples being analyzed in both analytical laboratories. At SDSU, laboratory reference materials 
Table 1. Isotopic ratios of amphipod groups and primary producers from an eelgrass bed in San Diego Bay, California. Also shown are no. of replicates, average no. of individuals per replicate, proportion of algae in the diet ( $\pm 95 \%$ CI) and trophic enrichment of amphipods

\begin{tabular}{|c|c|c|c|c|c|c|c|}
\hline Family & Genus & $\delta^{15} \mathrm{~N}$ & $\delta^{13} \mathrm{C}$ & Reps & Ind./rep. & $\%$ algae & $\delta^{15} \mathrm{~N}$ enrichment \\
\hline Ampithoidae & Ampithoe & $12.4 \pm 0.5$ & $-12.4 \pm 1.0$ & 10 & 11.5 & $39.2 \pm 16 \%$ & 1.7 \\
\hline Caprellidae & Caprella & $11.6 \pm 0.3$ & $-13.2 \pm 0.5$ & 10 & 12.9 & $49.7 \pm 13 \%$ & 0.9 \\
\hline Hyalidae & Protohyale & $11.5 \pm 0.4$ & $-9.7 \pm 0.3$ & 11 & 16.5 & $5.2 \pm 6 \%$ & 0.8 \\
\hline Ischyroceridae & Erichthonius & $12.4 \pm 0.2$ & $-14.0 \pm 0.9$ & 10 & 42.3 & $59.8 \pm 18 \%$ & 1.7 \\
\hline Oedicerotidae & Hartmanodes & $14.0 \pm 0.7$ & $-12.1 \pm 1.3$ & 4 & 4.5 & $35.9 \pm 19 \%$ & 3.3 \\
\hline \multicolumn{8}{|l|}{ Primary producers } \\
\hline Live eelgrass & & $10.7 \pm 0.5$ & $-8.3 \pm 0.4$ & 8 & 1 & & \\
\hline Detrital eelgrass & & $10.5 \pm 0.4$ & $-10.2 \pm 0.2$ & 8 & 1 & & \\
\hline Filamentous algae & & $11.0 \pm 0.5$ & $-17.2 \pm 1.8$ & 6 & $>100$ & & \\
\hline
\end{tabular}

were calibrated against NIST standard reference materials USGS40 and USGS41. Delta $(\delta)$ values for C and $\mathrm{N}$ were calculated using standard delta notation:

$$
\delta=\left(\frac{R_{\text {sample }}}{R_{\text {standard }}}-1\right) \times 1000
$$

where $R$ is the molar ratio of the heavy to light isotopes. Carbon and nitrogen isotope ratios are reported relative to the Vienna PDB scale (Coplen et al. 2006) and atmospheric $\mathrm{N}_{2}$ (Mariotti 1983), respectively.

A 2-source mixing model was used to estimate dietary composition of amphipod families using the equation:

$$
f=\frac{\delta^{13} C_{\text {amphipods }}-\delta^{13} C_{\text {eelgrass }}}{\delta^{13} C_{\text {algae }}-\delta^{13} C_{\text {eelgrass }}}
$$

where $f$ is the fraction of the diet derived from algae. The average $\delta^{13} \mathrm{C}$ values of producers used in the calculation were $-9.2 \pm 1.35 \%$ o for eelgrass (average of live and detrital eelgrass) and -17.2 \pm $4.5 \%$ for algae. Trophic enrichment was calculated as the mean difference between $\delta^{15} \mathrm{~N}$ values of each amphipod family and the average $\delta^{15} \mathrm{~N}$ value of primary producers $(10.7 \pm$ $1.7 \%$ ).

Statistical analysis. Outliers greater than $1.5 \times$ IQR (inter-quartile range) were identified and removed prior to analyses, resulting in less than $3 \%$ exclusion of data in analyses. Differences among amphipod families in $\delta^{13} \mathrm{C}$ and $\delta^{15} \mathrm{~N}$ values were examined using 1-way ANOVA. When significant, pairwise multiple comparisons among amphipod taxa were conducted using Tukey's HSD test. All statistical analyses were conducted using SYSTAT 12.01.02. We used 'IsoError' (Phillips \& Gregg 2001) and a 2-source mixing model to estimate the proportion of the diet of the amphipod families derived from eelgrass- vs. algae-based carbon sources. Errors were propagated and reported as $95 \%$ confidence intervals for the mixing-model results using IsoError software.

\section{RESULTS}

Carbon isotope signatures of eelgrass (mean of live and detrital) and algae differed by $8 \%$ and bracketed all amphipod $\delta^{13} \mathrm{C}$ values (Fig. 1). Significant differences in $\delta^{13} \mathrm{C}$ were detected among amphipod taxa $\left(F_{4,45}=5.7, \mathrm{p}=0.001\right)$, with hyalids showing a significantly higher $\delta^{13} \mathrm{C}$ than all other families. Oedicerotids were enriched in $\delta^{15} \mathrm{~N}$ relative to hyalids $\left(F_{4,45}=4.055\right.$, $\mathrm{p}=0.007$ ) and appeared to be partially carnivorous as suggested by their higher, but slightly overlapping, $\delta^{15} \mathrm{~N}$ values (Fig. 1) and greater trophic enrichment (Table 1). Caprellids, ischyrocerids, and ampithoids all exhibited intermediate $\delta^{13} \mathrm{C}$ and $\delta^{15} \mathrm{~N}$ values (Fig. 1,

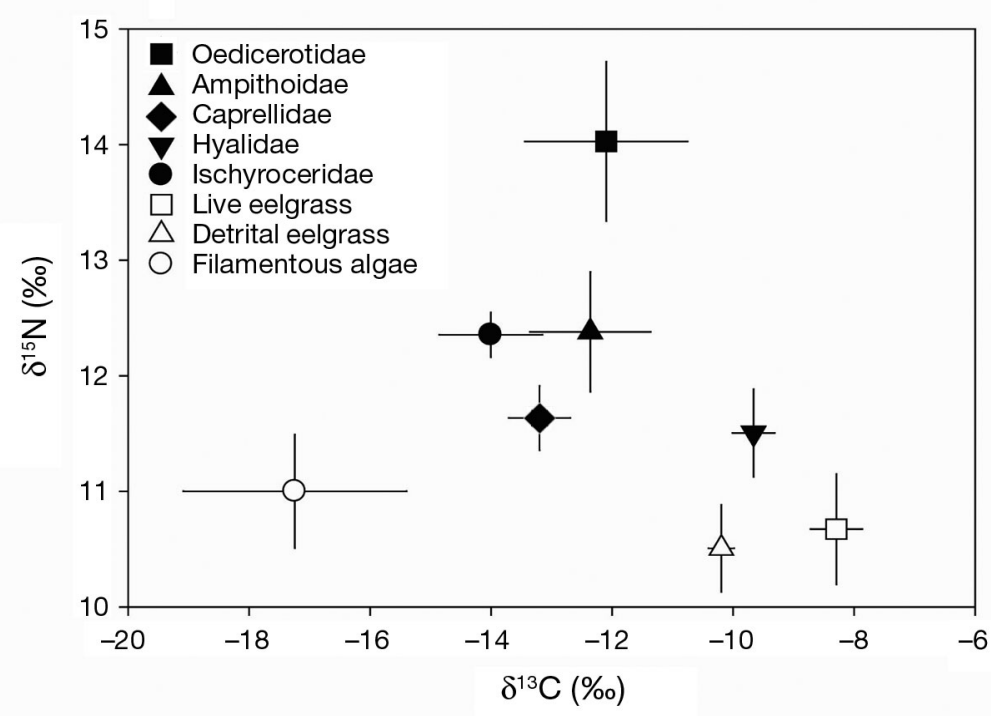

Fig. 1. Mean stable isotope ratios $( \pm 1 \mathrm{SE})$ of amphipod families (filled symbols), and primary producers (open symbols) from an eelgrass bed in San Diego Bay, California 
Table 1). The mixing model indicated that eelgrass production (live or detrital) constituted 94.8\% and $60.8 \%$ of the diet of hyalids and ampithoids, respectively. Algal production constituted $59.8 \%$ of the diet for ischyrocerids, whereas the mixing model indicated a relatively equal contribution of algae and eelgrass to the diet of caprellids.

\section{DISCUSSION}

We employed stable isotopes to explore timeintegrated differences in the diets of amphipod taxa in situ. Our findings are in general agreement with previous descriptions of family-specific feeding habits (Brawley \& Fei 1987, Dewey 1970, Dixon \& Moore 1997, Poore 1994, Duffy \& Harvilicz 2001, Chapman 2007, Poore et al. 2008). For example, intermediate $\delta^{13} \mathrm{C}$ signatures for ampithoids, caprellids and ischyrocerids agree with previous reports of heterogeneous feeding behaviors (Brawley \& Fei 1987, Dewey 1970, Duffy \& Harvilicz 2001), with our mixing model determining that ampithoids consume more eelgrass and ischyrocerids favor microalgae. Hyalids have previously been described as feeding on brown algae (Poore 2004). Our $\delta^{13} \mathrm{C}$ measurements suggest that hyalids were supported by eelgrass-derived carbon, which was in agreement with a macrophagous diet, but not in agreement with the source of carbon. Based on jaw morphology (adapted for consuming macrophytes), consumption of eelgrass in the absence of macroalgae in our study is a likely alternative feeding response. Oedicerotids are known to feed as predators on meiobenthic animals such as harpacticoid copepods (Yu \& Suh 2002), consistent with the enriched $\delta^{15} \mathrm{~N}$ values observed in our study. Assuming these oedicerotids were mostly carnivorous, our data suggest ca. $1.2 \%$ trophic enrichment, in agreement with the mean $\delta^{15} \mathrm{~N}$ enrichment (1.0 to $1.5 \%$ ) observed in similar ammonotelic marine crustaceans (McCutchan et al. 2003, Vanderklift \& Ponsard 2003).

Stable isotope analysis has been widely used for tracing the flow of carbon and nitrogen through foodwebs (Fry 2006). In light of its utility and common use in ecology, it is surprising that so few studies have used this tool to explore the functional roles of amphipods in nature. Gut contents of amphipods are often highly degraded and difficult to evaluate, and although feeding assays provide excellent information on what organisms prefer to eat in a laboratory, they are limited by the less realistic settings and reduced variety of food items offered (Duffy \& Hay 1991). By using stable isotopes, we were able to determine the relative importance of algal versus eelgrass production to feeding in amphipods, and their trophic position, in nature.
Furthermore, these signatures provide time-integrated diet histories (e.g. weeks to months) rather than instant snapshots in time (Kaufman et al. 2008). Though isotopic turnover can be influenced by temperature and several other factors (McIntyre \& Flecker 2006), stable isotopes have been shown to be fairly conserved throughout adult invertebrate life cycles (Fry \& Arnold 1982).

Our conclusions regarding the relative importance of eelgrass- versus algae-derived carbon and trophic position among amphipod taxa are likely robust and informative. We have demonstrated that stable isotopes can be used to assess the function of amphipods with respect to the dominant trophic pathways used while in their natural habitat. Such information is critical to our understanding of trophic dynamics in eelgrass ecosystems, for example, of how changes in topdown and bottom-up forcing are transmitted across trophic levels. In addition, by scaling studies such as ours to include a more comprehensive food web, ecologists can assess the relative importance of eelgrass and algal production in eelgrass ecosystems and how this importance may vary in space or time, or as a consequence of environmental change.

Acknowledgements. This research was supported by a grant from the Unified Port of San Diego, and we thank E. Maher and D. Merck. We also thank L. Thurn at the San Diego State University Ecology Analytical Lab for assistance with stable isotope analysis and R. Velarde and E. Moore at the San Diego City Metropolitan Waste Water District for assistance with identification of voucher specimens. A. Bohonak and P. Canning provided constructive comments on the manuscript, along with the anonymous reviewers whose comments improved the manuscript. This is Contribution No. 6 of the Coastal and Marine Institute Laboratory, San Diego State University.

\section{LITERATURE CITED}

Bell SS (1991) Amphipods as insect equivalents? An alternative view. Ecology 72:350-354

Brawley SH, Fei XG (1987) Studies of mesoherbivory in aquaria and in an unbarricaded mariculture farm on the Chinese coast. J Phycol 23:614-623

Chapman JW 2007. Amphipoda. In Carlton JT (ed) The Light and Smith manual: intertidal invertebrates from Central California to Oregon, 4th edn. University of California Press, Berkeley, CA, p 545-618.

Coplen TB, Brand WA, Gehre M, Groning M, Meijer HAJ, Toman B, Verkouteren RM (2006) New guidelines for $\delta^{13} \mathrm{C}$ measurements. Anal Chem 78:2439-2441

Currin CA, Newell SY, Paerl HW (1995) The role of standing dead Spartina alterniflora and benthic microalgae in saltmarsh food webs: considerations based on multiple stableisotope analysis. Mar Ecol Prog Ser 121:99-116

> Davenport AC, Anderson TW (2007) Positive indirect effects of reef fishes on kelp performance: the importance of mesograzers. Ecology 88:1548-1561

Dewey RA (1970) The feeding of Caprella equilibra. MS thesis, San Diego State University, CA 
Dixon IMT, Moore PG (1997) A comparative study on the tubes and feeding behaviour of eight species of corophioid Amphipoda and their bearing on phylogenetic relationships within the Corophioidea. Philos Trans R Soc Lond B Biol Sci 352:93-112

Duffy JE, Harvilicz AM (2001) Species-specific impacts of grazing amphipods in an eelgrass-bed community. Mar Ecol Prog Ser 223:201-211

Duffy JE, Hay ME (1991) Amphipods are not all created equal - a reply to Bell. Ecology 72:354-358

Duffy JE, Hay ME (2000) Strong impacts of grazing amphipods on the organization of a benthic community. Ecol Monogr 70:237-263

Fredriksen S (2003) Food web studies in a Norwegian kelp forest based on stable isotope $\left(\delta^{13} \mathrm{C}\right.$ and $\left.\delta^{15} \mathrm{~N}\right)$ analysis. Mar Ecol Prog Ser 260:71-81

Fry B (2006) Stable isotope ecology. Springer Science, New York, NY.

Fry B, Arnold C (1982) Rapid ${ }^{13} \mathrm{C} /{ }^{12} \mathrm{C}$ turnover during growth of brown shrimp (Penaeus aztecus). Oecologia 54: 200-204

Heck KL, Valentine JF (2007) The primacy of top-down effects in shallow benthic ecosystems. Estuar Coast 30: 371-381

Kaufman MR, Gradinger RR, Bluhm BA, O'Brien DM (2008) Using stable isotopes to asses carbon and nitrogen turnover in the Arctic sympagic amphipod Onisimus litoralis. Oecologia 158:11-22

Kitting CL, Fry B, Morgan MD (1984) Detection of inconspicuous epiphytic algae supporting food webs in seagrass meadows. Oecologia 62:145-149

Lewis LS (2009) Microcarnivorous fishes limit epifaunal abundance and enhance seagrass performance. MS thesis, San Diego State University, San Diego, CA

Mariotti A (1983) Atmospheric nitrogen is a reliable standard for natural ${ }^{15} \mathrm{~N}$ abundance measurements. Nature 303: 685-687

McCutchan JH, Lewis WM, Kendall C, McGrath CC (2003) Variation in trophic shift for stable isotope ratios of carbon, nitrogen, and sulfur. Oikos 102:378-390

McIntyre PB, Flecker AS (2006) Rapid turnover of tissue nitro-

Editorial responsibility: Joseph Pawlik, Wilmington, North Carolina, USA gen of primary consumers in tropical freshwaters. Oecologia 148:12-21

Moncreiff CA, Sullivan MJ (2001) Trophic importance of epiphytic algae in subtropical seagrass beds: evidence from multiple stable isotope analyses. Mar Ecol Prog Ser 215: 93-106

Nagelkerken I, van der Velde G, Verberk W, Dorenbosch M (2006) Segregation along multiple resource axes in a tropical seagrass fish community. Mar Ecol Prog Ser 308: 79-89

Orth RJ, Van Montfrans J (1984) Epiphyte-seagrass relationships with an emphasis on the role of micrograzing: A review. Aquat Bot 18:43-70

Paine RT (1980) Food webs: linkage, interaction strength and community infrastructure. J Anim Ecol 49:667-685

Peterson BJ, Fry B (1987) Stable isotopes in ecosystem studies. Annu Rev Ecol Syst 18:293-320

Phillips DL, Gregg JW (2001) Uncertainty in source partitioning using stable isotopes. Oecologia 127:171-179

> Poore AGB (1994) Selective herbivory by amphipods inhabiting the brown alga Zonaria angustata. Mar Ecol Prog Ser 107:113-123

> Poore AGB (2004) Spatial associations among algae affect host use in a herbivorous marine amphipod. Oecologia 140:104-112

Poore AGB, Hill NA, Sotka EE (2008) Phylogenetic and geographic variation in host breadth and composition by herbivorous amphipods in the family Ampithoidae. Evolution 62:21-38

Sala E, Graham MH (2002) Community-wide distribution of predator-prey interaction strength in kelp forests. Proc Natl Acad Sci USA 99:3678-3683

Thayer GW, Parker PL, Lacroix MW, Fry B (1978) Stable carbon isotops ratio of some components of an eelgrass, Zostera marina, bed. Oecologia 35:1-12

> Vanderklift MA, Ponsard S (2003) Sources of variation in consumer-diet $\delta 15 \mathrm{~N}$ enrichment: a meta-analysis. Oecologia 136:169-182

> Yu OH, Suh HL (2002) Secondary production of Synchelidium lenorostralum (Amphipoda, Oedicerotidae) on a temperate sandy shore, southern Korea. J Crustac Biol 22:467-473

Submitted: December 28, 2009; Accepted: October 13, 2010

Proofs received from author(s): November 30, 2010 